\title{
PENGETAHUAN DAN PERILAKU MAHASISWI UNIVERSITAS MUHADI SETIABUDI DALAM UPAYA PENCEGAHAN KANKER SERVIKS
}

\author{
Hanari Fajarini \\ Program Studi Farmasi Fakultas Ilmu Kesehatan Universitas Muhadi Setiabudi, Brebes \\ Indonesia \\ E-mail: hanari.fajarini@gmail.com
}

\begin{abstract}
Abstrak
Kanker serviks masih menjadi pembunuh kedua tertinggi setelah kanker payudara pada kebanyakan wanita di Indonesia. Kanker serviks dapat dicegah dengan melakukan vaksinasi, pemeriksaan Pap Smear maupun dengan menghindari faktor risiko penyebab kanker serviks. Telah dilakukan penelitian tentang pengetahuan dan perilaku mahasiswi Universitas Muhadi Setiabudi dalam upaya pencegahan kanker serviks. Penelitian dilakukan pada mahasiswi sebanyak 150 responden menggunakan metode observasional deskriptif. Instrumen penelitian yang digunakan adalah kuisioner yang terbagi atas 3 aspek, yaitu pengetahuan tentang kanker serviks, pengetahuan pencegahan kanker serviks dan perilaku pencegahannya. Dari penelitian ini didapatkan tingkat pengetahuan kanker leher rahim responden baik sebanyak 46,7\%, tingkat pengetahun Vaksin Human Papilloma Virus masih kurang yaitu 65,3\% dan tingkat pengetahun pap smear sedang yaitu 56,7\%. Ditemukan adanya perbedaan yang signifikan terhadap tingkat pengetahuan yang dimiliki oleh responden. Pada aspek perilaku, mayoritas responden berada dalam kategori netral yang menunjukkan belum adanya upaya lebih yang dilakukan oleh responden terkait pencegahan kanker serviks. Tingkat pengetahuan mahasiswi Universitas Muhadi Setiabudi terhadap pencegahan kanker leher rahim berdasarkan seluruh aspek baik, tetapi tingkat pengetahuan Vaksin Human Papilloma Virus dan pap smear masih kurang. Penelitian ini memberikan gambaran kepada institusi pendidikan untuk mensosialisasikan kanker serviks serta upaya pencegahannya.
\end{abstract}

Kata Kunci : kanker serviks, pencegahan, pengetahuan, perilaku, dan mahasiswi

\section{Abstract}

Cervical cancer is still the second highest killer after breast cancer in most women in Indonesia. Cervical cancer can be prevented by vaccinations, a Pap Smear test or by avoiding the risk factors causing cervical cancer. There has been research on the knowledge and behavior of students at Muhadi Setiabudi University in the prevention of cervical cancer. Research was conducted on a coed of 150 respondents using a descriptive observational method. The research instrument used is a questionnaire that is divided into three aspects, namely knowledge of cervical cancer, the knowledge of the prevention of cervical cancer and its prevention behavior. From this research obtained the rate of knowledge of cervical cancer respondents as much as 46.7\%, the knowledge rate of Human Papilloma Virus vaccine is still less that is $65.3 \%$ and the level of knowledge of moderate Pap smear is 56.7\%. There is a significant difference in the level of knowledge held by respondents. In the behavioral aspect, the majority of respondents were in neutral categories indicating no more effort was made by respondents regarding cervical cancer prevention. The 
level of knowledge from students at Muhadi Setiabudi University to cervical cancer prevention is based on all good aspects, but the level of knowledge of Human Papilloma vaccine Virus and Pap smear is still lacking. This research provides an overview of educational institutions to socialize cervical cancer and its prevention efforts.

Keywords: cervical cancer, prevention, knowledge, behavior, and students

\section{PENDAHULUAN}

Neoplasma ganas atau yang di kenal dengan kanker adalah penyakit pertumbuhan sel. Kanker terdiri dari sel-sel yang mempunyai bentuk, sifat dan kinetika yang berbeda dari sel normal asalnya. Pertumbuhannya liar, autonom, yang terlepas dari kendali pertumbuhan sel normal sehingga merusak bentuk atau fungsi organ yang terkena. Sebagian besar kanker itu terdapat pada orang dewasa atau tua di atas 35-40 tahun[1]. Kanker merupakan penyebab kematian terbanyak di dunia terhitung 7,6 juta jiwa atau sekitar 13\% dari seluruh penyebab kematian. Terdapat berbagai jenis kanker yang mengenai pria maupun wanita. Kanker yang sering mengenai wanita adalah kanker payudara dan kanker leher rahim. Kanker leher rahim merupakan kanker terbanyak kedua setelah kanker payudara (20\%) sekitar 13,1\% dengan mortalitas sebanyak 11,4\% [2]. Di Indonesia, kanker masih merupakan salah satu dari 10 penyebab kematian terbanyak. Dari data survei kesehatan rumah tangga (SKRT) 2001 kanker merupakan urutan ke-5 penyebab kematian umum sebesar 6\%. Sampai saat ini kanker leher rahim masih merupakan penyebab utama kematian pada wanita di Indonesia, di perkirakan 40 ribu kasus baru ditemukan setiap tahunnya. Di Rumah Sakit Dr. Cipto Mangunkusumo, frekuensi kanker leher rahim mencapai 76,2\% di antara kanker ginekologi[3].

Kanker leher rahim adalah penyakit yang sering di temukan pada wanita yang mengalami infeksi Human Papiloma Virus (HPV) tipe 16 atau 18. Sebab langsung dari kanker leher rahim belum di ketahui. Kemungkinan penyebab kanker leher rahim dipengaruhi oleh faktor ekstrinsik, diantaranya kemungkinan terkena kanker leher rahim lebih tinggi pada mereka yang kawin dari pada yang tidak kawin, terutama pada gadis yang koitus pertama pada usia dibawah 16 tahun. Insiden meningkat dengan tingginya paritas, apa lagi bila jarak persalinan terlampau dekat. Selain itu golongan sosial ekonomi yang rendah, merokok, serta aktivitas seksual yang sering berganti-ganti pasangan dengan higienis seksual yang jelek juga merupakan salah satu faktor resiko dari kanker leher rahim[4].

Terdapat beberapa cara untuk mencegah kanker leher rahim, upaya pencegahan primer ialah dengan Vaksin Human Papilloma Virus, pencegahan sekunder melalui usapan servikovaginal berkala dengan pengecatan papanicolaou atau yang dikenal dengan pap smear[4]. Remaja dapat memperoleh informasi mengenai kesehatan reproduksi dari berbagai sumber, namun sumber informasi yang diperoleh dari keluarga yang merupakan pendidik utama justru tidak mampu memberikan cukup informasi. Peran pendidik berikutnya yang sebenarnya mampu untuk memberikan informasi adalah sekolah atau perguruan tinggi[5][6]. Banyaknya kasus mengenai kesehatan reproduksi terutama mengenai perilaku seks membuktikan bahwa masih rendahnya pengetahuan kesehatan reproduksi hal ini dikarenakan mahasiswa belum menjadi sasaran program kesehatan reproduksi remaja, baik oleh pemerintah, maupun kalangan perguruan tinggi.[7]

\section{METODE PENELITIAN}

Penelitian ini mencakup bidang ilmu kesehatan khususnya kesehatan reproduksi. Penelitian ini merupakan penelitian observasional deskriptif. Desain ini dipilih karena tidak melakukan 
intervensi apapun dan survei hanya dilakukan satu kali. Penelitian dilakukan di Universitas Muhadi Setiabudi. Pengambilan data dilaksanakan pada bulan Maret sampai dengan Juni 2019. Populasi penelitian ini adalah mahasiswi yang menempuh pendidikan diploma dan sarjana dengan usia 16-21 tahun. Penentuan sampel dilakukan secara purposive random sampling. Pemilihan sekelompok subjek yang dianggap mempunyai sifat-sifat tertentu yang mewakili populasi. Setiap individu mempunyai kesempatan yang sama untuk dipilih sebagai sampel. Besar sampel yang akan diambil adalah 150 mahasiswi.

Variabel bebas penelitian ini adalah pendidikan formal mahasiswa. Variabel pendidikan formal ini berskala kategorial nominal. Sedangkan variabel tergantung penelitian ini adalah tingkat pengetahuan pencegahan kanker leher rahim. Variabel ini berskala kategorial ordinal: tingkat pengetahuan kurang, tingkat pengetahuan sedang, tingkat pengetahuan baik.

Alat penelitian menggunakan self-administered quesionnaire yang terkait dengan materi penelitian sesuai dengan validitas dan reliabilitas penelitian. Uji validitas dilakukan untuk menilai kesahihan isi kuesioner. Untuk tujuan ini dilakukan expert validity. Kuesioner dikirim kepada tiga orang pakar dan setiap pakar diminta menilai setiap pertanyaan kuesioner dengan skor: +1 $=$ pertanyaan berhubungan dengan pengetahuan kanker leher rahim; $0=$ tidak jelas berhubungan; - 1= pertanyaan tidak berhubungan dengan pengetahuan kanker leher rahim Pertanyaan dianggap valid bila nilai rata-rata skor lebih dari 0,5 . Data yang dikumpulkan merupakan data primer yang berasal dari pengisian kuesioner oleh responden. Analisis data menggunakan nilai persentase dengan rumus : F/Nx100\%

\section{HASIL DAN PEMBAHASAN}

Pada penelitian ini diambil sampel mahasiswa Universitas Muhadi Setiabudi sebanyak 150 mahasiswa. Bertambahnya usia seseorang mempengaruhi bertambahnya pengetahuan termasuk pengetahuan kesehatan reproduksi yang bisa juga diperoleh dari pengalamannya. Dalam penelitian ini dapat diketahui umur responden terdiri dari $6,7 \%$ berusia $16-17$ tahun, $82,0 \%$ berusia $18-19$ tahun dan $11,3 \%$ berusia diatas 19 tahun. Dalam ilmu psikologi perkembangan, umur dapat menggambarkan kematangan psikis dan sosial seseorang sehingga mempengaruhi baik tidaknya seseorang dalam proses belajar mengajar. Bertambahnya usia seseorang mempengaruhi bertambahnya pengetahuan termasuk pengetahuan kesehatan reproduksi yang bisa juga diperoleh dari pengalamannya[8] Dalam penelitian ini dapat diketahui umur responden terbanyak yaitu 18-19 tahun dimana pada usia ini responden sudah masuk pada masa remaja akhir yang stabil[9].

Persoalan yang sering muncul di mahasiswa sering dikaitkan dengan kontrol orang tua. Salah satunya adalah dengan melihat apakah mahasiswa tersebut tinggal bersama orang tua atau tidak. Penelitian menunjukkan sebagian besar dari responden tinggal di tempat kos yaitu sebanyak $23,2 \%$, tinggal bersama orang tua $70,7 \%$ dan 6,0 \% tinggal dirumah saudara. Penafsiran tergantung pada latar belakang mengapa responden tersebut tidak tinggal bersama orang tua mereka[10]. Keluarga mempunyai peranan penting sebagai sumber informasi khususnya informasi mengenai kesehatan reproduksi. Sebagian besar responden mendiskusikan kesehatan reproduksi dengan keluarganya, terutama kepada ibu. Pengaruh teman juga cukup mempengaruhi pengetahuan tentang kesehatan reproduksi karena sering mengadakan interaksi berkelompok[11]. Pengaruh kelompok sebaya akan tampak pada sikap, pembicaraan, penampilan, dan perilaku seseorang. Dukungan dari teman sebaya akan memperbesar kemampuan untuk memperoleh pola perilaku sosial yang lebih matang[8]. Rendahnya jumlah responden yang merokok yaitu $4,7 \%$ menunjukan bahwa sudah tingginya kesadaran responden terhadap rokok yang merupakan salah satu faktor resiko terjadinya kanker leher rahim. Aktifitas pada kegiatan yang dapat meningkatkan informasi mengenai kesehatan reproduksi masih rendah. Hanya 4,7\% responden yang mengikuti kegiatan mengenai

JOPHUS Vol.01, No. 1, Agustus 2019: 18 - 22 
kesehatan reproduksi khususnya kanker leher rahim. Hal tersebut dimungkinkan karena belum banyaknya kegiatan yang bergerak di bidang kesehatan reproduksi. Di Universitas Muhadi Setiabudi sendiri belum terdapat kegiatan kemasyarakatan yang bergerak dibidang tersebut. Lingkungan geografis dan besar kemampuan ekonomi dapat berpengaruh terhadap penyediaan serta kesempatan dalam memperoleh informasi kesehatan reproduksi. Dalam penelitian ini diketahui responden jarang memperoleh sarana informasi mendapatkan kesempatan dalam memperoleh informasi kesehatan reproduksi.

Dalam penelitian responden sebagian besar sudah memperoleh informasi pencegahan kanker leher rahim. Dapat kita lihat dari baiknya tingkat pengetahuan kanker leher rahim yaitu 46,7\%. Sumber informasi mengenai kanker leher rahim didapat dari matakuliah dan dosen, tapi terkadang informasi yang didapat dari pendidikan formal belum mencukupi, sehingga responden sering mencari informasi dari sumber lain seperti media massa[5]. Tingkat pengetahuan kanker leher rahim yang baik tidak disertai dengan baiknya tingkat pengetahuan Vaksin Human Papilloma Virus dan pap smear. Hal ini dapat disebabkan karena masih kurangnya kegiatan di Fakultas dan Universitas mengenai pencegahan kanker leher rahim yang merupakan salah satu pencegahan primer dan sekunder kanker leher rahim[12]. Responden lebih memahami tentang pencegahan sekunder kanker leher rahim, dibandingkan pencegahan primer kanker leher rahim. Pencegahan kanker leher rahim yang terbaik adalah dengan melakukan vaksinasi dan pap smear karena jangkauan perlindungan vaksin tidak mencapai 100\%[13].

Dalam penelitian ini juga dapat dilihat bahwa sumber informasi yang diharapkan tidak sesuai dengan sumber informasi yang di dapat, dimana seminar yang diharapkan mampu meningkatkan pengetahuan pencegahan kanker leher rahim ternyata tidak sesuai dengan sumber informasi yang tersedia. Dalam hal ini orang tua, guru sekolah dan teman lebih berperan penting dalam mendapatkan informasi mengenai pencegahan kanker leher rahim. Hal ini dapat dikarenakan:

a. Keluarga merupakan kelompok sosial utama dimana seseorang belajar. Dari keluarga pula remaja dapat memperoleh pengetahuan mengenai kesehatan reproduksi[14]

b. Sebagian besar waktu remaja umtuk memperoleh pengetahuan ada di sekolah. Maka adanya kurikulum mengenai kesehatan reproduksi dapat mempengaruhi pengetahuan mengenai kesehatan reproduksi[15]

c. Dukungan dari kelompok sebaya akan memperbesar kemampuan remaja untuk memperoleh pola perilaku sosial yang lebih matang yang akan tampak pada sikap, pembicaraan, penampilan, dan perilaku seseorang[8]

\section{KESIMPULAN}

Tingkat pengetahuan mahasiswi Universitas Muhadi Setiabudi terhadap pencegahan kanker leher rahim berdasarkan seluruh aspek sudah baik, tetapi tingkat pengetahuan Vaksin Human Papilloma Virus dan pap smear masih kurang.

\section{DAFTAR PUSTAKA}

[1] Sukardja, I. G., 2000, Onkologi klinik. Surabaya: Airlangga University Press.

[2] Globocan, 2008, Fast Fact : Less Developed Regions, Available from http://globocan.iarc.fr/factsheets/populations/factsheet.asp?uno=902\#BOTH. Diakses juli 2019 
[3] Rasjidi, Imam., 2008, Manual Prakanker Serviks. Jakarta: CV Sagung Seto.

[4] Sarwono, P., 2009, Ilmu kandungan, Jakarta: Yayasan Bina Pustaka

[5] United Nations Population Fund, 2010, Adolescent Realities in a changing world. Available from www.unfpa.org/adolescent/about.htm diakses bulan Desember 2018

[6] Sarwono, P., 2005, Bunga Rampai Obsetri dan Ginekologi Sosial. Jakarta: Yayasan Bina Pustaka.

[7] Badan Koordinasi Keluarga Berencana Nasional., 2009, Mahasiswa Belum Banyak Tahu Dampak Seks Pra Nikah, Available from http://www.bkkbn.go.id/Webs/DetailRubrik.php?MyID=596 diakses November 2010

[8] Hurlock, E.B., 1997, Psikologi Perkembangan: Suatu Pendekatan Sepanjang Masa. Edisi kelima. Jakarta: Erlangga.

[9] Singgih, D. G., 2007, Psikologi Remaja. Jakarta: Gunung Mulia.

[10] Sarwono, W.S., 2000, Psikologi Remaja. Jakarta: PT. Raja Grafindo Persada.

[11] Santrock, J.W., 2003, Adolescence: Perkembangan Remaja. Edisi keenam. Jakarta: Erlangga.

[12] Rasjidi, I., 2009, Deteksi Dini \& Pencegahan Kanker pada Wanita. Jakarta: Sagung Seto.

[13] Andrijono., 2010, Kanker Serviks Edisi Ketiga. Jakarta: Divisi Onkologi Departemen Obstetri-Ginekologi FKUI.

[14] Wijayanti, E., 2000, Beberapa faktor yang berpengaruh terhadap pengetahuan kesehatan reproduksi remaja di desa Bancak, Laporan Penelitian.

[15] M, Kilbourne Brook., 2000, Kesehatan Reproduksi Remaja: Membangun Perubahan yang Bermakna. Washington: PATH. 